\title{
Role of Solar energy and issues in its implementation in the Indian context
}

\author{
Saurav Dixit ${ }^{1,}$, Subhav Singh ${ }^{2}$, Sonali Singh ${ }^{3,}$ Richu George Varghese ${ }^{1}$, Amit Kumar Pandey ${ }^{4}$, and Deekshant Varshney $^{2}$ \\ ${ }^{1}$ RICS School of Built Environment, Amity University, Noida, India \\ ${ }^{2} \mathrm{~K}$ R Mangalam University, Gurgaon, India \\ ${ }^{3}$ Jaipuria Institute of Management, Noida, India \\ ${ }^{4}$ Amity Business School, Amity University, Noida, India
}

\begin{abstract}
The main objectives of using renewable energy enable us to attain sustainable growth without compromising the future. India is on the 7th nation in generating renewable energy while the USA, China and Germany are on 1st, 2nd, and 3rd respectively. Secondly, in case of Solar energy, the statistics are: India is on the 7th nation in generating solar energy while China, Japan, and Germany are on 1st, 2nd, and 3rd respectively, Generating 9, 78, 42.8 and $41.2(\mathrm{GW})$ gigawatts from solar power. India having great opportunities in generating solar power because of its location and the availability of largely unused land banks throughout the nation. The purpose of the paper is to examine the challenges to the adoption of solar energy as a means of generation of energy and power for the nation's requirement. The hurdles/factors identified for the study is 16 and a targeted data collection of 105 for the study using convenient sampling technique throughout India. The research finding shall contribute to the existing body of knowledge and provide suggestions to the policymakers, the manufactures and the local bodies working on the ground to implement the solar energy as an alternate energy resource to fossil fuels in India.
\end{abstract}

Keywords: Renewable Energy; Sustainable Energy; Non-Conventional Energy India; and Issues.

\section{Introduction}

Fast population development has brought about expanding demands for energy requirement and in addition becoming ecological concerns. It has additionally uncovered the imperatives of conventional energy. This has created a worldwide requirement for government approaches that truly consider sustainable power source innovations (SPSI). The strong connection between sustainable power source SPS) and sustainable development is provoking nations around the world to receive SPSI in order to guarantee sustainable development. It has been contended that multiplying the present execution of SPS era can decrease $\mathrm{CO} 2$ outflow to $349 \mathrm{~g} / \mathrm{KWh}$, which is not as much as the $498 \mathrm{~g} / \mathrm{KWh}$ focused for 2030. This will keep environmental CO2 beneath 450 parts for every million, which is required to counteract serious atmosphere change [1].

It has been assessed that $88 \%$ of the world's vitality utilization is from non-renewable energy source [2]. Air contamination, human-prompted environmental change, vitality supply weakness and cost increments are a portion of the issues related to petroleum derivative that has offered ascend to the usage of SPSI over the world.
The cosy relationship amongst SPS and sustainable development has provoked a few governments worldwide to present laws that advance SPS.

There is in this way an unfaltering development in the utilization of renewables around the world. By 2013, RE gave an expected $19.1 \%$ of worldwide vitality utilization. Of this aggregate offer, conventional biomass represented around $9 \%$, Hydropower $3.9 \%$, inexhaustible warmth $4.1 \%$, and transport biofuels gave around $0.8 \%$. By 2014 , renewables rose to an expected $27.7 \%$ of the force to be reckoned with's creating a limit, which was sufficient to supply an expected $22.8 \%$ of worldwide power [3].

\section{Literature review}

Hydropower limit ascended by $3.6 \%$ to roughly 1055 $\mathrm{GW}$, while different renewables all in all developed from about $18 \%$ to an expected aggregate drawing nearer 660 GW (REN21 2015). This was nearly trailed by the National Renewable Vitality Master Plan (NREMP) in 2005. NREMP imagined national reasonable

* Corresponding author: sdixit@ricssbe.edu.in 
advancement through the usage of SPSI (Sambo 2009b), with the desire of a $10 \%$ RE entrance by 2020 . Regardless of Nigeria's rich RE assets, the nation is still vigorously dependent on petroleum derivatives. The difficulties encompassing the usage of SPSI are ascribed to the low level of open mindfulness, costs, financing imperatives furthermore, powerless innovation scattering systems. Other factors incorporate an absence of shopper certainty due to poor item quality, an absence of sufficient approach, and an absence of gifted labour. As indicated by Okafor what's more, financial, social, specialized, what's more, political (counting instructive) obstructions must be overcome for the correct coordination of RE into the country's vitality blend. It has been contended that the acknowledgement of SPSI by the open is related to the general population's convictions, mentality also, the impression of such innovation. Open dispositions need to change to make significant improvements as far as the execution of SPSI doable. Open (social) acknowledgement abbreviates the time, what's more, their usage [4] [5].

It is thus that training on REs is respected as fundamental for the effective usage of SPSI and for open help. Instruction as an intense operator of social change not just brings issues to light about new improvements what's more, items; it likewise makes open trust in new items, what's more, prepares the general population to utilize them effectively [6] [7] recommends that the Nigerian government ought to sharpen the open, and also aid the production of business sectors for RE frameworks. And agrees by belligerence for the joining of RE training into the Nigerian instructive framework.

Table 1 issues/hurdles in solar energy implementation identified from the literature review and expert interview

\begin{tabular}{|l|}
\hline Initial investment/high cost \\
\hline Affordable/economical \\
\hline Setting-up cost \\
\hline Price to quality ratio/Profitability \\
\hline Environment-friendly \\
\hline Lack of policy \\
\hline Lack of government initiative \\
\hline Space requirement \\
\hline Lack of knowledge \\
\hline Reuse/recycle \\
\hline Availability of raw material \\
\hline Convenience of use \\
\hline Uncertain power output \\
\hline Lack of robust design \\
\hline Automatic operation \\
\hline Variation in electricity prices \\
\hline
\end{tabular}

\subsection{Objectives of the study}

I. To determine the factors influencing the companies to adopt sustainable supply chain management practices.

II. To prioritise the attributes on the basis of their relative importance index on various companies in the transition towards SSCM.

\section{Research Methodology}

For this research paper, a questionnaire survey method has been used to identify and analyse the hurdles/issues in the implementation of solar energy in India. For this, the structured questionnaire survey is shared with the professionals, the potential, and existing customers of solar energy. The received data were analyzed using Relative importance index (RII), relative importance index (Rii) was applied to prioritise the severity of the factors" [1] [2] [3] [4] and other techniques.

Quantitative research methodology is adopted for the study. The data is collected using structured questionnaire survey. Primary data has been collected for the study because of non-availability of secondary data on the said tittle. The convenience sampling technique is used to collect the data from the known and easily approachable respondents. The questionnaire is shared with 300 professionals working in different segments of the economy including but not limited to manufacturing, production, suppliers, customers, construction, energy, and others sectors. A total of 105 valid responses were received with a response rate of $35 \%$.

The structured questionnaire is divided into three parts: the first portion has information about the topic and general study that is to be conducted, the second part is the questionnaire itself and the last portion consists the feedback and any suggestion for the study by the respondents. The respondents were asked to rate the questions on the Likert scale of 1-5 given against each question.

\subsection{Reliability analysis}

Dependability analysis is needed to check the consistency of the model after some time, and Cronbach's alpha test was the best way to check the reliability of the data collected through questionnaire [5]. The value of Cronbach's alpha for this study is 0.76 which is considered to be good for the study.

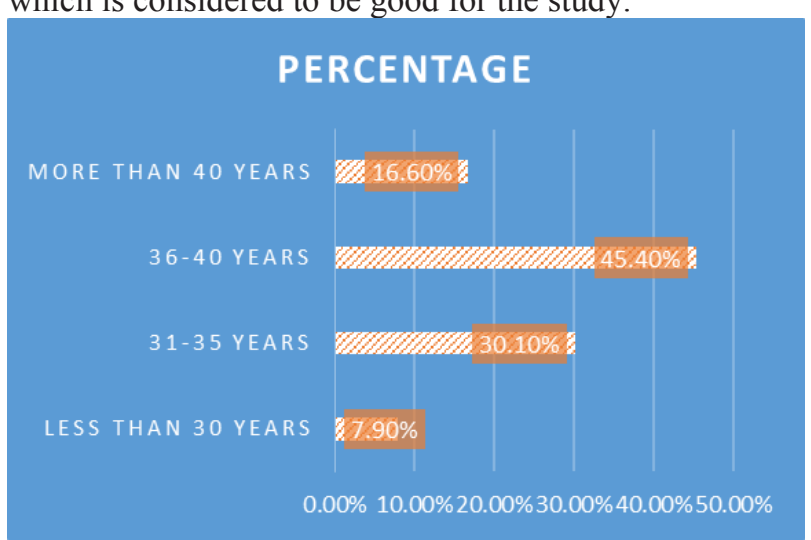

Fig 1 respondents age profile 
Table 2 relative importance index ranking

\begin{tabular}{|c|c|c|c|c|}
\hline $\begin{array}{c}\text { Ran } \\
k\end{array}$ & $\begin{array}{c}\text { Total } \\
\text { respons } \\
\text { es }\end{array}$ & $\begin{array}{l}\text { Total } \\
\text { score }\end{array}$ & $R I I$ & Attribute name \\
\hline 1 & 105 & 467 & 0.89 & $\begin{array}{c}\text { Initial } \\
\text { investment/high cost }\end{array}$ \\
\hline 2 & 105 & 444 & 0.85 & Setting-up cost \\
\hline 3 & 105 & 426 & 0.69 & $\begin{array}{c}\text { Lack of government } \\
\text { initiative }\end{array}$ \\
\hline 4 & 105 & 425 & 0.69 & Lack of knowledge \\
\hline 5 & 105 & 413 & 0.69 & Reuse/recycle \\
\hline 6 & 105 & 395 & 0.68 & Convenience of use \\
\hline 7 & 105 & 393 & 0.68 & $\begin{array}{c}\text { Uncertain power } \\
\text { output }\end{array}$ \\
\hline 8 & 105 & 392 & 0.67 & $\begin{array}{l}\text { Lack of robust } \\
\text { design }\end{array}$ \\
\hline 9 & 105 & 391 & 0.67 & $\begin{array}{c}\text { Variation in } \\
\text { electricity prices }\end{array}$ \\
\hline 10 & 105 & 385 & 0.67 & Automatic operation \\
\hline 11 & 105 & 384 & 0.67 & $\begin{array}{c}\text { Availability of raw } \\
\text { material }\end{array}$ \\
\hline 12 & 105 & 378 & 0.67 & Space requirement \\
\hline 13 & 105 & 363 & 0.67 & $\begin{array}{c}\text { Affordable/economi } \\
\text { cal }\end{array}$ \\
\hline 14 & 105 & 359 & 0.66 & $\begin{array}{l}\text { Price to quality } \\
\text { ratio/Profitability }\end{array}$ \\
\hline 15 & 105 & 332 & 0.66 & $\begin{array}{c}\text { Environment } \\
\text { friendly }\end{array}$ \\
\hline 16 & 105 & 327 & 0.66 & Lack of policy \\
\hline
\end{tabular}

\subsection{Relative importance index}

The received responses by the respondents were summarized in an Excel data sheet and the data analysed using SPSS software. Relative importance indices (RII) is performed to determine the priority of the significant factors and then followed by Reliability analysis performed to check the consistency of the data received. Rii $=\frac{\sum_{x=1}^{5} x^{*} n_{2}}{5 \mathrm{~N}}$

$r$ is the rating on a Likert scale (1-5) as for the impact on construction efficiency for a specific element influencing construction profitability, $\mathrm{nr}$ is the number of respondents providing a specific Likert scale rating $r, \mathrm{~N}$ is the aggregate number of respondents to a specific question [6][4], [16], [17].

The value given to the Likert scale rating is as follows:
1. No effect ( or no opinion)
2. Less effect (no or minimal effect)
3. Minor effect (minor problem)
4. Serious effect (medium problem)
5. Very serious effect (major problem

Table 3 Relative importance index

\subsection{Most significant issues and hurdles}

The significant issues and hurdles in the implementation of solar energy in Indian context are convenience of use, uncertain power output, lack of robust design, variation in electricity prices, and automation in operation having a relative importance index value by analyzing the received data is $68 \%, 67 \%, 67 \%, 67 \%$ and $67 \%$ respectively.

\subsection{Significant issues and hurdles}

The significant benefits through the transition towards SSCM are environmental benefits, competitive advantages, reduced carbon footprints, inventory control and helps in circular economy having a relative importance index value of $0.68,0.68,0.67,0.67$, and 0.67 respectively.

\section{Discussion and conclusion}

The study identified the current scenario of solar energy and the trends in the world, and in India. The contribution of India to solar energy production is $9 \mathrm{GW}$ and it is in the 7 position. There is three type of establishment in solar energy are a government project, private projects, and individual household solar plants installation. There is a huge potential in all the three segments as mentioned above for the implementation of solar energy.

The main issues and hurdles in the expansion of solar plants were identified and analysed using RII and the top issues are mostly related to cost associated with the implementation of the plants. There are few schemes that provide subsidies on the installation of solar plants, but there is a loophole in these schemes i.e. the schemes provide subsidies amount on the purchase of solar panels and storage batteries only if they were purchased from the government agencies. And the item rate of these agencies is comparatively high to the private and locally available solar panels and batteries in the market. It is recommended to provide subsidies amount irrespective of the vendor or the market to all the traders working in the solar industry. The study provides an insight into the barriers in the functioning and expansion of solar energy in India.

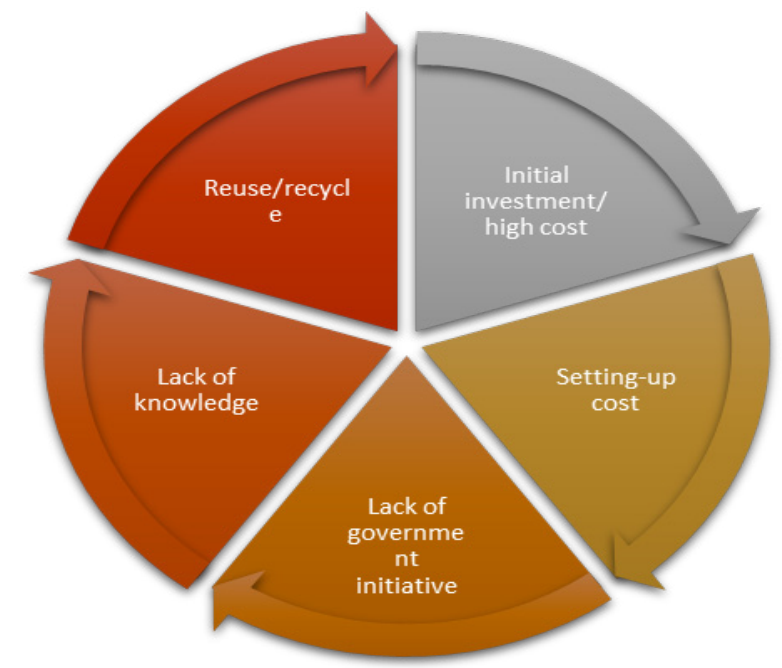

Fig 2 Top five issues/hurdles in the implementation of solar energy 


\section{Limitations of the study}

The study is conducted using structured questionnaire survey and collection of primary data. The received responses are 105 considered for this study is comparatively small to generalise the findings to the larger scale [19]. It is recommended to conduct a similar kind of study in different regions of the country to have a better understanding of the issues and the hurdles in the implementation of solar energy as an alternative to the conventional energy sources in the Indian context

\section{References}

[1] IRENA, Remap 2030: Renewable Energy Prospects for India, no. May. 2017.

[2] R. Singh, B. B. Krishna, J. Kumar, and T. Bhaskar, "Bioresour. Technol., vol. 199, pp. 398-407, 2016.

[3] M. S. Bhaskar, R. M. Kulkarni, S. Padmanaban, P. Siano, and F. Blaabjerg, EEEIC 2016 - Int. Conf. Environ. Electr. Eng., pp. 1-6, 2016.

[4] I. A. Urzúa, J. C. Olmedo, and E. E. Sauma, Renew. Sustain. Energy Rev., vol. 60, pp. 810821, 2016.

[5] A. Sao, S. Singh, S. Dixit, A. K. Pandey, and S. Singh, Int. J. Mech. Eng. Technol., vol. 8, no. 10, 2017.

[6] J. Cloke, A. Mohr, and E. Brown, Energy Res. Soc. Sci., no. June, pp. 0-1, 2017.

[7] A. K. Pandey, S. Dixit, S. Bansal, S. Saproo, and S. N. Mandal, Int. J. Civ. Eng. Technol., vol. 8, no. 10, 2017.

[8] C. Rodríguez-Monroy, G. Mármol-Acitores, and G. Nilsson-Cifuentes, Renew. Sustain. Energy Rev., vol. 81, no. June 2017, pp. 937-945, 2018.

[9] S. Dixit, A. K. Pandey, S. N. Mandal, and S. Bansal, Int. J. Civ. Eng. Technol., vol. 8, no. 6, 2017.

[10] C. Fogarassy and S. Istv, The ... Reykjaví k University Renewable Energy Summer Course Circular Economy Extracurricular Reykjaví k , 2017," no. August, 2017.

[11] A. Tapaninen, M. Seppänen, and S. Mäkinen, "Characteristics of innovation in adopting a renewable residential energy system," J. Syst. Inf. Technol., vol. 11, no. 4, pp. 347-366, 2009.

[12] V. Khare, S. Nema, and P. Baredar, Renew. Sustain. Energy Rev., vol. 58, pp. 23-33, 2016.

[13] A. Basu, B. Kumar, and T. K. Rana, pp. 52-55, 2017.

[14] L. Kong, Z. Li, L. Liang, and J. Xie, Ind. Manag. Data Syst., vol. 117, no. 6, pp. 1145-1165, 2017.

[15] S. Dixit, S. N. Mandal, A. Sawhney, and S. Singh, Int. J. Civ. Eng. Technol., vol. 8, no. 8, pp. 623-636, 2017.

[16] D. Castro-Lacouture and K. O. Roper, Facilities, vol. 27 , no. 5/6, pp. 173-186, 2009.

[17] S. Griffiths, Energy Transitions, vol. 1, no. 1, p. 3, 2017.
[18] R. N. Wojuola and B. P. Alant, African J. Sci. Technol. Innov. Dev., vol. 9, no. 4, pp. 399-409, 2017.

[19] S. Singh, A. Bala, S. Dixit, and D. Varshney, Int. J. Civ. Eng. Technol., vol. 9, no. 1, 2018. 